\title{
DETERMINANTS OF DIGITAL BANKING CONVENIENCE AND CUSTOMER SATISFACTION OF SELECTED DEPOSIT MONEY BANKS IN NIGERIA
}

\author{
${ }^{1}$ Kofoworola Sekinat Ogboye \\ Department of Finance, School of Management Sciences, Babcock University \\ Ilishan-Remo, Ogun State, Nigeria \\ ${ }^{2}$ Folorunso I. Akande (Ph.D) \\ Department of Finance, School of Management Sciences, Babcock University \\ Ilishan-Remo, Ogun State, Nigeria \\ ${ }^{3}$ Jerry Kwarbai (Ph.D) \\ Department of Accounting, School of Management Sciences, Babcock University \\ Ilishan-Remo, Ogun State, Nigeria
}

\begin{abstract}
Citation: Kofoworola Sekinat Ogboye, Folorunso I, Akande and, Jerry Kwarbai (2022) Determinants of Digital Banking Convenience and Customer Satisfaction of Selected Deposit Money Banks in Nigeria, European Journal of Accounting, Auditing and Finance Research, Vol.10, No. 2, pp.1-30
\end{abstract}

\begin{abstract}
The banking industry has enjoyed customer loyalty for over a decade with a high customer retention rate across board but the emergence of technology within the banking sector has aroused the interest of customer to switch from one bank to the other. Worst still, competitors from adjacent information technology driven industries and other financial organization are now flooding the market with innovative, creative and technology-driven idea which is a deviation from the conventional banking system and customers now are making decisions much faster and have access to a plethora of offers, leaving financial institutions struggling for customer loyalty. Therefore, the study examined the determinants of digital banking convenience and its effect on customers' satisfaction in selected money deposit banks in Lagos State, Nigeria.The research designs adopted for this study was survey research design. The target population for this study was customers of the selected deposit money banks in Lagos State, Nigeria. The sample size for the study was 140 and simple random sampling technique was adopted for the study. The research instrument was questionnaire which was validated by the supervisor and the reliability was 0.731 . The data for the study were analysed using simple regression analysis.The study showed that digital banking has significant effect on customers' satisfaction in selected deposit money banks in Lagos State, Nigeria. The finding also revealed that speed of delivery has significant effect on customers' satisfaction of deposit money banks in Lagos State, Nigeria with Adj $R^{2}=0.173 ;$ F-Statistics $\left._{(d f}=4,432\right)=27.559$ and $p$ value $=0.000$. The study revealed that ease of use has significantly effect on customers' satisfaction of customers in deposit money banks in Lagos state Nigeria with Adj $R^{2}=0.340 ; F-$ Statistics $\left._{(d f}=4,432\right) .=66.312$ and $p$-value $=0.000$. The study concluded that customers prefer digital banking services which would pave for sustainable development to the banking industry. It is however recommended the gains of this innovation should be consolidated through provision of more service points and user-friendly customer-oriented financial products.

KEYWORDS: Accessibility, Age and Attitude of Customers, Ease of use, Education, Privacy and Security, Speed of Delivery
\end{abstract}

ECRTD-UK: https://www.eajournals.org/

Journal level DOI: https://doi.org/10.37745/ejaafr.2013 


\section{INTRODUCTION}

Globalization has impacted the manner and ways in which businesses are done. Presently, consumers' desires are also changing and the way companies deliver service must also change in order to survive. Consumers' expectations are gradually changing, expecting a seamless, highquality experience across all digital channels, including on-line and mobile. These changes are more pronounced in financial institutions, as such financial institutions are responding to consumers' demands by providing digital channels and developing new systems and features to satisfy customers, but much of digital banking transformation potential remains unrealized. Banking sectors in most developed countries have pioneered the area of e-services and have been actively involved in its continuous improvement (Sinisalo \& Salo, 2007). This is an indication that customers' satisfaction is the most important factor for the long term survival of any organization, especially the banking industry where depositors and lenders are the assets of the bank. Hence, developing nations like Nigeria are also not left behind.

All over the world, banks now realize that only those that overhaul their payment service delivery and operations are likely to survive and prosper in the 21st century (Babatunde \& Salawudeen 2017). This is due to the pressure of globalization and digitalization of operations. In order to operate efficiently in a competitive business environment and be one of those companies to be reckoned with in the new century, banks are making use of digital banking channels to execute their operation. The purpose of applying digital banking is to ensure speedy, convenient and reliable service to customers. This implies that customers are king and acknowledging the place of the customers is key to the growth and survival of businesses (Naeem, Muniba, Qurat-ul-ain \& Amna, 2016).

According to Seyed, Razieh and Ali (2015), many banks have installed modern computer interconnectivity backbone that would enable them achieve communication of data and multimedia over internets, intranets and extranets. The overall purpose of rapid progresses in technology is targeted to offer financial services to their customers in exchange for monetary rewards. Since banks depend totally on their customers for their returns, there is a growing need to meet up with the ever-changing needs of the society caused by technological advancement and continuous improvement in the quality of services (Marcel \& Prisca, 2015).

Nigerian banks have, no doubt invested much on technology; and have widely adopted electronic and telecommunication networks for delivering a wide range of value added products and services. They have in the last few years transformed from manual to automated systems. Unlike before when ledger-cards were used, today banking has been connected to information technology networks, thereby facilitating the practice of inter-branch and inter-bank transactions. Also, the introduction of mobile telephone in 2001, improved access to personal computers and internet service facilities have contributed to the growth of electronic banking in the Nigerian banking sector (Seyed, Razieh \& Ali, 2015). However, Ondiege in 2010 claimed that in Africa, majority

ECRTD-UK: https://www.eajournals.org/

Journal level DOI: https://doi.org/10.37745/ejaafr.2013 
of the population has no access to banking services, with only $20 \%$ of African families having bank accounts. There is limited access to financial services in Africa stemming particularly from deficient infrastructure, physical geographical isolation or inaccessibility and financial illiteracy. Even Africans with bank accounts often face high charges for moving their cash around, due to high transactions costs. Kumar (2014) revealed that in Africa many are now living in the digital area and this is now forcing many banks to revisit their customer service efforts.

The key factor in accepting digital banking is the reliability and satisfaction of customers towards the bank which indirectly affects digital banking acceptance. On the other hand, the participation of the customers is highly important in digital banking acceptance; since it will result in reduction of the interactions between the organization and the customers. Customer and bank participation is a factor which affects the quality of services, satisfaction and finally customer maintenance; meanwhile most people are conservative about using new technologies (Sarokolaei, Rahimipoor, Nadimi, \& Taheri, 2012). Customer satisfaction is likely to be even more important online, since it is harder to keep online customers loyal. Unlike traditional banking which is characterized by direct contact service, the lack of direct human interaction in internet banking requires the need to examine the determinants of digital banking convenience and its effect on customer satisfaction. Thus, banks must have the knowledge on how to get their customer satisfied, especially in relation to digital banking (Khorasani-Zavareha, Bigdelic, Eslamlou, Abdoosd \& Mohammadib 2012).

Therefore, it can be deduced from the above assertions that when bank managers satisfy the need of the customer by delivering quality service, it will enhance competitive advantage of their firms and also increase profitability (Amoah-Mensah, 2010). According to Saha and Zhao (2005), the importance of reliable quality service delivery cannot be over emphasized, the authors identified that reliability means honoring the commitments in areas such as billing accuracy, proper record maintenance and delivering the service within acceptable time limit. Furthermore, Zeithaml and Bitner (2000) argued that customers are specifically influenced by the reliability of new technology because they might be associated with risks such as the technology malfunctioning (AmoahMensah, 2010). Moreover, Karim and Chowdhury (2014) emphasized that companies are placing a high priority on customer satisfaction which is critical to improved organizational performance in a global market scenario. This implies that with better understanding of customers' satisfaction, banks can determine the actions required to meet their customers' needs. They can identify their strengths and weaknesses, where they stand in comparison to their competitors and they can chart out path for future progress and improvement (Santhiyavalli, 2011).

From the above assertions, it is gathered that customer satisfaction is central to the marketing concept, with evidence of strategic links between satisfactions and service performance (Truch, 2006). Customer satisfaction is considered to act as an antecedent of loyalty and retention, arising out of direct prior experience (Wu \& Wang, 2005) which can lead to short term and long term achievement of the firm. Thus, this study examined the determinants of digital banking convenience and its effect on customer satisfaction in selected deposit money banks in Lagos State.

ECRTD-UK: https://www.eajournals.org/

Journal level DOI: https://doi.org/10.37745/ejaafr.2013 
In spite of efforts pooled together by bank management and regulatory authorities to enhance customer satisfaction and convenience at all times, customers continues to experience dissatisfaction in banking services coupled with incessant transaction errors, slow service delivery, network failure and frequent digital banking system downtime. Babatunde and Salawudeen (2017) identified that customers perceive digital banking as a risky channel rather than the conventional banking; highlighting that the digital banking delivery channels such as Automated Teller Machine (ATM), Point of Sale, mobile banking and internet banking installed by banks to handle customers financial needs fail repeatedly to dispense cash as at when necessary. This has affected the transactions of customers and led to series of complaints, poor patronage of bank digital services, customer dissatisfaction and customer disloyalty.

Also, bank customers are being swindled by internet hackers through digital banking channels. Customer's personal information, security details and privacy are assessed by internet fraudsters or 'yahoo boys', this is a recurring problem in Nigeria. According to the World Bank (2014), bank fraud in Nigeria is one of the highest in the world. Another source of customer irritation and dissatisfaction is in the challenge of accessibility and reliability of digital services.

Bank customers are dissatisfied when they pay extra fees for using other banks ATM, owing to the inability of their banks to locate Automated Teller Machine within reach. Similarly, banks charge extra fees for moving cash from one bank to another even when they place a minimum on what is allowable. Beside the dissatisfaction coming from bank policy structure on digital banking, customers are frustrated by the poor service delivery of most digital platforms. These service delivery ranges from inability to access account through digital channels, poor or unavailable online customer service, loss of privacy, security bridges from internet fraudsters and data reliability challenges. These issues basically defeat not only the key ingredients of digital banking but raise concern for banks in meeting their customer satisfaction objectives. This study in consideration of these problems, and in an effort to contribute and extend the frontiers in literature, investigated the determinants of digital banking convenience and its effect on customers satisfaction in selected deposit money banks in Lagos State.

\section{Objectives of the Study}

To determine the effect of speed of delivery of digital banking on customers' satisfaction of deposit money banks in Lagos State, Nigeria.

To examine the effect of ease of use of digital banking on customers' satisfaction of deposit money banks in Lagos State, Nigeria.

To investigate the controlling effect of education, age and attitude of customers on digital banking adoptions and customers' satisfaction of deposit money banks in Lagos State, Nigeria.

ECRTD-UK: https://www.eajournals.org/

Journal level DOI: https://doi.org/10.37745/ejaafr.2013 


\section{Research questions}

What is the effect of speed of delivery of digital banking on customers' satisfaction of deposit money banks in Lagos State, Nigeria?

What effect does ease of use of digital banking has on customers' satisfaction of deposit money bank in Lagos State, Nigeria?

What is the controlling effect of education, age and attitude of customers on digital banking adoptions and customers' satisfaction of deposit money banks in Lagos State, Nigeria?

\section{Research Hypotheses}

$\mathrm{H}_{01}$ : Speed of delivery has no significant effect on customers' satisfaction of deposit money banks in Lagos State, Nigeria.

$\mathrm{H}_{02}$ : Ease of use has no significant effect on customers' satisfaction of deposit money banks in Lagos state, Nigeria.

$\mathrm{H}_{03}$ : Education, age and attitude of customers has no controlling effect on digital banking adoption and customer satisfaction of deposit money banks in Lagos State, Nigeria?

\section{REVIEW OF RELATED LITERATURE}

\section{Digital Banking Convenience}

Digital banking convenience refers to refers to the accessibility and expediency of the delivery of digital banking to enhance customers' satisfaction. According to Vasya and Patrickv (2006), recent development of information technology has led to major changes in the way services are delivered to the customers. Nowadays, customers are using more and more self-service options, which are more convenient and fast. Kumar (2014) suggested that customers' growing use of digital banking channels for banking and their demand for an individualized experience have forced many banks to revisit their customer service efforts. In the face of increasing competition from emerging digital banks, which are redefining customer satisfaction and luring younger customers, traditional banks must leverage digital channels to create a more rewarding customer satisfaction. The study also points out that for a successful transition to digital banking, banks must formulate a strategy focused on six key areas: customer, mobile and online capabilities, use of customer data, social media, modernized branches/ATMs and provision for a seamless experience across all channels (Mammasse \& Schlich 2014).

Some banks that have adopted the digital banking channels like internet banking are being faced with various obstacles like teething problems ranging from security concerns by the users, lack of adequate legal framework, poor marketing strategies and issues regarding the connectivity of internet banking site; all these affects the perceived convenience on digital banking platform thereby leading to customers dissatisfaction. Moreover, digital banking convenience gives traditional banks a second chance to deepen customer satisfaction and loyalty, driving long-term relationships and profitability with the approach also embracing the potential to meet consumers' expectations and bring efficient banking back to the customers. Gallino and Moreno (2014)

ECRTD-UK: https://www.eajournals.org/

Journal level DOI: https://doi.org/10.37745/ejaafr.2013 
highlights that banks are facing a growing challenge from non-bank entities that are aggressively using digital innovations to take on functions traditionally part of banking. He gives an example Amazon, which now offers loans to its merchants and the giant Alibaba (Chinese E-Commerce Company with the Largest IPO in US Stock History), now the world's largest payment provider. However, according to Kevin and Harriet (2015) banks have a huge competitive advantage in this digital world. With their vast digital data, payment know-how and deep understanding of compliance, security and financing, they are positioned to become an everyday bank, providing an unparalleled personalized customer satisfaction that cannot be replicated by non-banks. Digital and mobile technology allows banks to access new pools from banked or unbanked population across the globe and customer behaviors' changing extensively.

Adeyemi, Ola and Oyewole (2014) state that digital banking convenience has played an important role in improving service delivery standards in the banking industry. In its simplest form, Automated Teller Machines (ATMs), Point of Sale Terminals (POS) and deposit machines now allow consumers carry out banking transactions beyond banking hours and these have enhanced customers' satisfaction globally, Nigeria inclusive. Banks with higher levels of quality service will have higher levels of customer satisfaction as an introduction for achieving sustainable competitive advantage. Adoption of digital banking channels by customers has proved to be of many advantages to the banking sector in Nigeria. It offers numerous advantages like enabling customers to remotely withdraw and deposit money in banks at any time, transfer money as well as well proper data management and record keeping. However, banks face many challenges; among them are difficulty in convincing computer illiterate customers to adopt digital banking channels and also getting well-trained ICT professionals.

\section{Speed of Delivery}

The speed of operations and rapid responsiveness has always attracted the attention and it is a main concern of digital banking and information systems (Asadollah, Hossein \& Abbas, 2014). Likewise, there is a significant relationship between the speed of downloading and users' satisfaction. Download speed depends on the content of materials, computing hardware and connection method (Zhengwei, 2010). Speed which refers to the duration of response is highly considered in digital banking due to increase focus on the efficiency of operational resources. In advanced economies, users are sensitive to the speed of services. Therefore, speed and timeliness of digital platforms are two vital considerations (Swaid \& Wigand, 2007; Yoon, 2010). Hence, they are considered as important factors in users' satisfaction and one of the main measures to evaluate websites (Aldawani \& Palvia, 2002). Yoon (2010) noted that in advanced economies, customers are more sensitive to the speed of received services. Therefore, speed is a factor to prevent time wasting and as a radical consideration to attract the satisfaction of customers from digital banking services.

Furthermore, customers are particularly interested in the speed with which digital banking services are offered or delivered (Asadollah, Hossein \& Abbas, 2014). (In addition, most researches have

ECRTD-UK: https://www.eajournals.org/

Journal level DOI: https://doi.org/10.37745/ejaafr.2013 
indicated that in most cases, customers overrate the processing time of a service (Yoon, 2010). Base on the above, Swaid and Wigand (2007) posited that on certain occasion customers have strong preferences to carry out digital banking services on platforms that are fast and reliable. Also, Asadollah, Hossein and Abass (2014) resolved that slow service delivery has a negative effect on individuals overall perceptions of the digital banking service quality. Therefore, this implies that speed of delivery is a major determinant of digital banking convenience and customers' satisfaction in relation to usage of digital banking channels.

\section{Ease of Use}

Ease of use deals with the navigation ability of the website, how the links are arranged, presented and easy to navigate, the web address is easy to remember, the website is straight forward and the terms of using the site are easily understandable (Ahmad \& Al-Zu'bi, 2011). Yang and Fang (2004) found that ease of use is an important factor that determines digital banking convenience. In a simple definition, one can say that ease of use in digital banking is the comfort of using online services such as internet banking, telephone banking, mobile bank and ATMs (Yoon, 2010).

Furthermore, ease of use describes the extent to which innovative digital banking products are easy to understand and operate. Digital banking channels which customers perceive as difficult to understand may be underutilized, since they would require much time and effort to master such channels. Black (2001) noted that digital banking platforms which customers perceive as complex will take a lot of time to be adopted by the customers. In other words, ease of use is expected to have a positive influence on acceptability and convenience of digital banking channels. Similarly, Ahmad and Al-Zu'bi (2011) established that the ease of use of digital banking products positively influences convenience and customer satisfaction.

\section{Customers' Satisfaction}

According to Asadollah, Hossein and Abbas (2014) customer's satisfaction is a mood or reaction by consumer to buy and consume a product. In marketing terms, customer's satisfaction is intertwined with the experience of buying goods or services. When the outcomes are evaluated by customers, they are in turn comparing the results of their own experiences with expected results. In other words, customer's satisfaction is a degree of positive feeling of customer to service provider (Lee \& Chung, 2009). According to Jamal and Naser (2002), customer's satisfaction is a response to consumer's expectations and answering the radical question of whether the product/service which was provided delivered an enjoyable level of consumption or not). Customer's satisfaction is a mode by which the customer feels that product specifications are in accordance to his/her expectations. Asadollah, Hossein and Abass (2014) believes that customer's satisfaction is a feeling in psychological terms that is the result of comparing the products with customers' needs and demands as well as social expectations from the products. Similarly, according to Wang and Jen (2006), customer satisfaction is defined as the performances levels of service quality that meets consumers desires, while Monireh, Asadollah and Reza (2014) in their

ECRTD-UK: https://www.eajournals.org/

Journal level DOI: https://doi.org/10.37745/ejaafr.2013 
view defined customers' satisfaction as a positive feeling that is created in every person after using goods or services of a service provider.

Customer satisfaction may be termed as a business philosophy which tends to create value to customers through fulfilling various responsibilities. It is also viewed as a tool for measuring banks' ability to meet or exceed customers' needs (Bareerah \& Muhammad, 2014). Customer satisfaction depends on the ability of management to breach the gap between a customer's expectation and the reality of the features embedded in a product or service through interactions with the customers. The success or failure of any bank depends on customer satisfaction (Anyim, Ikemefuna, \& Mbah, 2011). According McMullen and Bergman (2017), a frustrated customer should not be expected to maintain a long-term relationship with the company since his or her needs have not been met by the institution.

According to Maxham (2014), customer satisfaction is the ability of a service provider or an organisation to accomplish the business, emotional, and psychological need of its customers. In the words of Oliver (2010), customer satisfaction is the summary psychological state resulting when the emotion surrounding disconfirmed expectations is coupled with the consumer's prior feelings about the consumption experience. Hunt (2011) defined customer satisfaction as an evaluation rendered that the consumption and customers' experience was at least as good as it was supposed to be. In a study by Sreejesh and Mohapatra (2013), they opined that customers' satisfaction is an evaluation that the chosen alternative is consistent with prior beliefs with respect to that alternative. It is a well-researched fact that investments in customer relation, service quality, and customer satisfaction result in high profitability and market share.

If customers are pleased with a particular service delivery, then the customers can be expected to engage in future purchases and by extensions there would be an improvement on the market share of the organization. Customer satisfaction implies that a customer or the user of a service is contented with the service delivery (Johnson \& Fornell, 1991). One of the advantages of customers' satisfaction, according to Anderson (2014) is that customer satisfaction is used as an important metric in marketing, since firms regard customer satisfaction as one of the key business goals for evaluating the effectiveness of their business operations. Indeed, firms have invested a great amount of money on this metric, as customer satisfaction investments represent an important marketing research expenditure item for most firms. Customer satisfaction can be seen as an essential measure used to oversee business outcomes, decide on limited resource allocation, and provide rewards to management. For some firms, the pursuit of these metrics may not produce the desired outcome.

ECRTD-UK: https://www.eajournals.org/

Journal level DOI: https://doi.org/10.37745/ejaafr.2013 


\section{THEORETICAL REVIEW}

\section{Financial Intermediation Theory}

The financial intermediation theory was developed by Leland and Pyle in 1977. The theory emphasized the roles of the financial intermediaries in the financial systems. The theory establishes that the contribution of intermediaries is to ensure steady flow of the funds from the surplus unit to the deficit units. The role of financial intermediaries is essential in that it ensures the growth of the economy through supply of financial commodities (Scholten and Wensveen, 2003). The financial intermediaries ensure the creation of a platform that enables transaction of different commodities. The financial intermediaries exist due to the market imperfections. As such, in perfect market situation, with no transaction or information costs, financial intermediaries would not have existed. Numerous financial markets are characterized by informational differences between buyers and sellers.

Furthermore, the financial intermediary theory analyzes the functions and roles of financial intermediaries in the economy, the way in which the financial intermediation influences the economy on the whole and the effects of government policies on financial intermediaries. Most of the studies performed highlight their roles in achieving a durable economic growth, and the impact of regulations on financial intermediation, accentuating the role of regulatory authorities in the supervision and control of financial intermediaries.

The financial intermediation theory is based on the assumption of the presence of informational asymmetry and the agency theory. In principle, the existence of financial intermediaries is explained by the existence of the following categories of factors: high cost of transaction, lack of complete information in useful time; and the method of regulation. In financial markets, information asymmetries are particularly pronounced. Investors tend to borrow with the collateral and entrepreneurs have inside information about their own investment seeking financing. It explains the importance of intermediation process of financial intermediaries in the economy as a whole.

In support of the financial intermediary theory, Shittu (2012) emphasized that intermediaries eliminate (or reduce) the need for self-financing of investments. In particular, by providing liquidity, financial institutions permit risk averse savers to hold deposits rather than liquid (but unproductive) assets. The funds obtained by the deposit money banks are then available for investment in productive capital. Hence, deposit money banks should finance any positive net present value project if the cost of investment is below the expected returns

The financial intermediation theory is criticized on the ground that it is heavily focused on the functions of financial institutions that are no longer crucial in mature financial systems. Also the emphasis of financial intermediation theory on the role of intermediaries as reducing the frictions of transaction costs and asymmetric information is too strong; while these factors may once have been central to the role of intermediaries, they are increasingly less relevant. Shittu (2012)

ECRTD-UK: https://www.eajournals.org/

Journal level DOI: https://doi.org/10.37745/ejaafr.2013 
suggested a view on financial intermediaries that centers on two roles. First, they are the facilitators of risk transfer and deal with an increasingly complex maze of financial instruments and markets. The key area of intermediary activity therefore has become risk management, whereas traditional intermediation theory offers little to explain why institutions should perform this function.

The financial intermediation theory is relevant to this study as it emphasizes the functions of deposit money banks in mobilizing, channeling, pooling savings and increasing investment levels in the economy, thus improving their efficiency and expanding their functions through technological innovation contributes immensely to the growth of the economy.

\section{Silber's Constraint Theory of Innovation}

This theory was coined by Silber in 1975 with the aim of describing the reasons of digital banking innovation in financial institutions. The concept of constraint theory of innovation is based on the notion that digital banking enhances profitability of firms through the speed of delivery of services. The theory views that banks have both internal and external constraints which can be managed through adoption of technologically enabled process. Therefore, through harnessing the power of technology, banks can enhance customer satisfaction which in turn leads to cost reduction (Gakure \& Ngumi, 2013).

This theory is based on the assumption that digital banking channels in financial service industry tends to attract more customers to banks product which also saves the bank in huge administrative cost. This implies that digital banking is in two folds; one it serves as a means of saving cost for financial institutions and secondly it is a tool for enhancing customers' satisfaction. In support of Silber's Constraint Theory of Innovation, Gakure and Ngumi (2013) noted that banks that were not innovative had poor performance when compared with banks that engaged in product development through digital banking, this implies that digital banking drives customers' satisfaction.

Husein (2013) criticized this theory and noted that Silber's constraint theory of innovation focused attention majorly on the benefit of digital banking channels to financial institutions rather than the advantages of such innovations in the aspect of service quality and customer satisfaction.

This theory is important to this study as it provides an alternative explanation suggesting that operational constraints in the banking environment can be curbed through robust and effective digital banking channels. The theory is thus applicable in this study since it postulates that digital banking enhances the operational performance of financial institutions.

\section{Theoretical Framework}

This study reviewed two theories in the literature. These theories are Financial Intermediation Theory and Silber's Constraint Theory. Considering the determinants of digital banking convenience and customers' satisfaction of deposit money banks, this study focused on the two Theories reviewed. These theories are of the opinion that digital banking tends to attract more customers to banks product, saves the bank in huge administrative cost and also improves the

ECRTD-UK: https://www.eajournals.org/ 
customer satisfaction of deposit money banks. Also, the theories postulate that deposit money banks basically provide payment mechanism which is part of their financial intermediation function. Therefore, the payment mechanism function of deposit money banks can be improved through adoption of digital banking. Moreover, through harnessing the power of technology, banks can improve service delivery which in turn leads to customers' satisfaction.

\section{Empirical Review}

\section{Speed of Delivery and Customers' Satisfaction}

Ariff, Yuan, Zakuan and Ismail (2013) study examined the relationship and the impacts of e-SQ and e-Satisfaction on e-Loyalty in internet banking. The modified version of E-SERVQUAL instrument was used to determine e-SQ for internet banking service of a commercial bank in Malaysia. Questionnaires were collected randomly from 265 internet banking users. The findings indicated that assurance-fulfillment, efficiency-system availability; privacy, contactresponsiveness and website aesthetics and guide constitute e-SQ for the internet banking service. Website aesthetics and Guide, Efficiency-System availability and Contact-Responsiveness of the internet banking e-SQ were positively affected e-Satisfaction. E Satisfaction was positively significant to e-Loyalty. E-Satisfaction was found to partially mediate the relationship of Website aesthetics and Guide of e-SQ and customer e-Loyalty. The result highlighted that attractiveness and appearance, and the information and guidance provided by the websites are important features to internet banking users. This finding reflected that in internet banking, beside the technical and functionality aspects of -SQ, such as efficiency, fulfillment and system availability, the aesthetic value and proper guidance of the websites are also crucial to ensure quality of e-SQ that will lead to e-Satisfaction and e-Loyalty.

Adeyemi, Ola and Oyewole (2014) study investigated the impact of internet banking on the customer satisfaction level in banking sector of Nigeria. A structured questionnaire was used to collect data from a sample of Ninety (90) customers of different banks in Nigeria. Data collected were analyzed using regression Analysis with the aid of Statistical Package for Social Sciences (SPSS) software version 20. The result showed that the independent variables (i.e internet banking and quality service) were significant joint predictors of customer satisfaction $(\mathrm{F}(2,87)=$ $91.3035 ; \mathrm{R} 2=0.677 ; \mathrm{P}<.01)$. The independent variables jointly explained $67.74 \%$ of variance of customer satisfaction. This paper recommends that banks' customers should be educated on how to make use of internet banking products and Nigeria government should also enact a law that will govern internet banking which will not allow unfair and deceptive trade practice by the supplier and unauthorized access by hackers.

Seyed, Razieh and Ali (2015) research evaluated the effect electronic banking and three dimensions comprise quality of system, quality of information and quality of service in customer loyalty with regard to role of customer satisfaction among customers of mellat bank in Isfahan city in Iran. The population of the study comprises customers of mellat bank in Isfahan city that make

ECRTD-UK: https://www.eajournals.org/

Journal level DOI: https://doi.org/10.37745/ejaafr.2013 
use of total electronic banking service, therefore the population of research is unlimited and uncounted. The instrument of data collection in this research is standard questionnaire. Number of 250 questionnaire distributed and totally 224 questionnaires were analyzed. Samples were also selected with method of available random. To analyze data and test hypotheses was used pls and Spss software. The results indicate that system quality has a positive and significant impact on customer satisfaction. On the other hand, results indicate that information quality has a positive and significant impact on customer satisfaction. Also, the effect of customer satisfaction in customer loyalty is confirmed.

Alice, Elizabeth and Gregory (2016) investigated the effect of mobile banking on customer satisfaction in selected banks in Trans-Nzoia County. The study was guided by the following objectives: to establish the effect of reliability of mobile banking on customer satisfaction, to determine the effect of responsiveness of mobile banking on customer satisfaction, and to evaluate the effect of accessibility of mobile banking services on customer satisfaction in Trans-Nzoia County. A descriptive survey research design was adopted. The target population was ten selected banks in Trans-Nzoia County. The study was guided by the; innovation diffusion theory, technology acceptance model (TAM), and theory of reasoned action (TRA). The study adopted the descriptive survey research design with the target population being the selected commercial banks personnel in Trans Nzoia County, totaling to 41 respondents. Census method was adopted since the target population was less than the minimum a hundred for sampling to be used for research. A structured questionnaire was used as a data collection instrument that was designed in a Likert scale format. Data analysis was carried out by use of regression and ANOVA using the Statistical Package for Social Sciences (SPSS) version 23 in order to statistically produce the relationship between the independent variables and dependent variable. From the findings, the researcher concluded that the regression effect was statistically significant indicating a reliable prediction of the dependent variable. The $F$ calculated $(F=39.96)$ greater than $5 \%$ level of significance thereby showing that the model was significant where the independent variables explained $85 \%$ of the mobile banking customer satisfaction. The study was significant to the banking sector since mobile banking is a phenomenon that has taken off and can't be washed away. Babatunde and Salawudeen (2017) examined the impact of electronic banking in Nigerian banking industry and financial institutions. The paper uses both the primary and secondary data to elicit information from the forty $(40)$ respondents. The primary data were collected through the use of questionnaire, while the secondary data were obtained from the publications of the Central Bank of Nigeria Electronic Banking Guideline, Annual Reports of the CBN and Access Bank Plc. The population selected was designed to obtain adequate and diverse views pertaining to the level and impact of electronic banking in Access Bank. The paper employs both descriptive and inferential statistics to analyse the data. In addition, simple frequency counts, percentages and the Chi-square were used in the data analysis. Findings show that 22 credit officers or $62.9 \%$ of respondents agree with the opinion that electronic banking system has made banking transactions easier, 11 credit officers representing $31.45 \%$ strongly agree, while 2 of them representing $5.7 \%$ were undecided and none of the respondents neither disagree nor strongly disagree. The paper concludes that the

ECRTD-UK: https://www.eajournals.org/

Journal level DOI: https://doi.org/10.37745/ejaafr.2013 
adoption of electronic banking has enhanced the bank's efficiency, making it more productive and effective.

\section{Ease of Use and Customers' Satisfaction}

Mohsin, Arshad, Saleem and Kashif (2011) study formulated and tested a model for customer satisfaction based on service quality in e-banking. The research team developed the model on the basis of theoretical background. The research team used a structured questionnaire in order to collect data from e-banking customers of private sector banks in Pakistan using the convenience sampling method. The sample size of the study was 264. The research team used SPSS 15.0 to examine the variables. The research team also used virtual partial least squares (VPLS) 1.04 for model testing in a single run. The findings validated the relationships between the variables in the model. The outcome of the study was that identified service quality dimensions had a significant impact on customer satisfaction in e-banking. Improvement in web service quality was recommended for achievement of customer satisfaction in banking sector.

Gupta and Bansal (2012) developed an instrument for measuring Internet banking service quality in India and also analyzed the impact of Internet banking service quality dimensions on the Overall Internet Banking Service Quality and customer satisfaction. To measure service quality they also developed scale of 22 items. Exploratory factor analysis resulted into five dimensions: Security/Privacy, Reliability, Efficiency, Responsiveness, and Site Aesthetics. Model was further validated through Confirmatory Factor Analysis. A survey was carried on some mixed sample of 1350 Internet banking customers of private sector, public sector and foreign banks in the Delhi Metropolitan Area. Results of multiple regression analysis revealed that security/Privacy dimension carry the maximum impact on the Overall Internet Banking Service Quality whereas customer satisfaction is most impacted by the Efficiency dimension as compared to other dimensions.

Tasmin, Abubakar, Norazlin and Josu (2013) study was about the impact of online banking on customer service delivery in Malaysian banking industry. Due to the challenges of globalization and intensive competition, Banks were compelled to comprehend the services of online banking in order to entice the existing and the potential customers. Although, the level of awareness is relatively high; but still only $64 \%$ patronize online banking in Malaysia. It is against this background that this paper seeks to examine the significant factors that may cause online banking to have an impact on customer service delivery with the ultimate aim of either accepting or rejecting any preconceived idea of the researcher. The study employed some hypotheses in order to guide the research in achieving the overall aim of the research as well as testing the stated hypotheses. Behavioral factors such as security, convenience and cost were the main concern of the respondents towards effective service delivery. The study reveals that "Cost" is the major driver of effective service delivery of online banking services in Malaysia. Equally, the study also explores various implications of the research.

ECRTD-UK: https://www.eajournals.org/

Journal level DOI: https://doi.org/10.37745/ejaafr.2013 
Asadollah Hossein and Abbas (2014) study was conducted to evaluate and identify the most important e-baking service quality Dimensions in Iranian banking industry which would finally yield to more customers' satisfaction and Brand Equity. A questionnaire was used in the study. The sample consists of 384 customers of Tehran bank. Structural Equation Model (SEM) and Confirmatory Factor Analysis (CFA), LISREL and SPSS software packages were used to analyze data. The findings indicated that Accessibility, Easiness, Trust, Security, Website designing, Website content, Speed and Commission had an effect on satisfaction and Brand Equity.

Geeta and Surendra (2014) empirical study was to explore internet banking service quality factors and also analyze its impact on customer satisfaction through Multiple-Regression statistical techniques. A structured Likert scale-based questionnaire was prepared with the help of literature and filled by internet banking users of Indore district of Madhya Pradesh through survey method. Using factor analysis five dimensions for internet service quality were extracted and to analyze its impact on customer satisfaction regression method was used by the researcher. Researcher found that there is a positive impact of service quality dimensions on customer satisfaction. Regression measures have indicated that website ease of use, comfort, accessibility, are influential factors, whereas, confidence and responsiveness also have significant impact on satisfaction of the online customers.

Muhsina and Imran (2015) study sought to identify the most influential factors of customer satisfaction of mobile banking of second - generation banks. Study mainly followed a quantitative research methodology while structured questionnaire used as main data collection instrument. In collecting primary data, survey technique used as data collection tool and random sampling procedure used for selecting respondents of this study. Data analysis performed using through ANOVA, multiple regressions, and cross tabulation. Study found that, there exist strong associative relationships between the customer satisfactions with the selected factors. It is also found that, the security and trust factor is the most influential factor where ineffective advertisement has negative influence on the customer satisfaction of mobile banking.

Worku, Tilahun and Tafa (2016) study presents what impact electronic banking has on customer satisfaction in comparing with traditional bank and other banking service, its relationship with that of age, occupation and education, its impact on branch visits, the level of customer understanding about e-banking and the opportunities and challenges of e-banking. The paper tried to see all the above among 402 properly filled and returned questionnaires of e-banking customers and interview with four branches of the two commercial banks which have started e-banking service in Gondar city when this study was conducted. The study used tables, percentages, chi-square independency test to see the relationship between demographic characteristics and e-banking, independency t-test to see if the visits of branches before and after e-banking by customers is significant or not and regression analysis test has been conducted to explain the variables which determine customers' satisfaction in e-banking. The results of the study implied that majority of users of e-banking are the young, the educated, salaried and students, business men and women

ECRTD-UK: https://www.eajournals.org/

Journal level DOI: https://doi.org/10.37745/ejaafr.2013 
are not actively using the service of e-banking and there is also a relationship between e-banking and demographic characteristics, e-banking currently provided for saving and current accounts holders only, e-banking has improved customer satisfaction, reduced frequency of bank hall for banking service, reduced waiting time for customers, there are customers who don't know the fee charged for being e-banking users, the bank customers' satisfaction increased after being ebanking users, enabled customers to control their account movements and there is high opportunity to expand e-banking service in the city.

\section{METHODOLOGY}

The survey research design was adopted for this study. The survey research design was carried out using primary data through the use of questionnaire which was not be manipulated. Through this design, the use questionnaire is considered appropriate as a method of retrieving information for data collection and classification. The study considered the views of respondents from the selected deposit money banks in Lagos State, Nigeria. The justification for using survey research design was based on its capability for collecting enormous data; it is also useful in describing the characteristics of a large population extensively. Survey research is unique in gathering information not available from other sources and it gives an unbiased representation of population of interest.

\section{Population}

The target population for this research was the employees and customers of selected deposit money banks in Lagos State, Nigeria. The selected banks includes; First Bank Nigeria Plc, Wema bank, Guarantee Trust Bank Plc, Zenith Bank Plc, Polaris (Skye) bank Nigeria Plc and diamond Bank Plc now Access Bank Plc. The total population of respondents in this category is 2,358 employees from the selected deposit money banks (NIBSS, 2016).

\section{Sample size and sampling Technique}

In order to collect an unbiased sample for the study and because this study is targeted at employees and customers of the selected deposit money banks in Lagos State, a random sampling technique was employed for the study so as to give all respondents an equal chance of being represented in the study. The objective of research work is to draw inference from the sample of the population in order to make generalization on the whole population. However, because of the large population involved in most studies, researchers hardly study the entire population. Therefore, sample was drawn from the study population from the banks in Lagos State. Therefore, the researcher adopted Yaro Yamane formula to determine the sample size. Thus, the sample size was derived using the formula below;

$$
\mathrm{n}=\frac{\mathrm{N}}{1+\mathrm{N}\left(\mathrm{e}^{2}\right)}
$$

Where $\mathrm{n}=$ appropriate sample size

ECRTD-UK: https://www.eajournals.org/ 
$\mathrm{N}=$ population size

$\mathrm{e}=$ co-efficient or confidence margin or error unit

$\mathrm{e}=5 \%$ pr 0.05

Thus, the sample size is calculated as;

$$
\begin{gathered}
\mathrm{n}=\frac{2358}{1+2358\left(0.05^{2}\right)} \\
\mathrm{n}=\frac{2358}{1+5.895} \\
\mathrm{n}=\frac{2358}{6.895} \\
\mathrm{n}=140 \\
\mathrm{n}=140
\end{gathered}
$$

To this end therefore, 140 respondents constituted the sample size for this research study.

\section{Research Instrument}

The research instrument is a device for collecting the data or measuring the variable which are used for answering research questions and/or testing hypothesis. The research instrument that was used for this study is an adopted semi structured questionnaire. A questionnaire is a document that consists of a set of leading questions which logically are arranged and are to be filled by the respondent himself. Semi-structured questionnaires will be adopted since they offer the researcher an opportunity to collect both structured and unstructured data. This is important in research since standardized data makes it easy to conduct analysis and to draw inferences, while at the same time, open ended questions offered respondents opportunity to clarify their answers in the structured section. The questionnaire was divided into five sections. Section 1 covers demographic factors, while section 2 to 5 covers independent and dependent variable consecutively.

The research instrument designed for this study is a 5-point Likert scale questionnaire aimed at eliciting the respondent's perception of the determinants of digital banking convenience and its effect on customers' satisfaction. The 5-point Likert scale questionnaire ranges from strongly agree to strongly disagree, on all the questions, '5' would represent Strongly Agree (SA); '4' would represent Agree (A); '3' would represent Disagree (D); '2' would represent Strongly Disagree (SD) and ' 1 ' would represent Undecided (U).

\section{Model Specification}

The model in this study followed the study of Worku, Tilahun and Tafa (2016) where they examined the effect of electronic banking on customer satisfaction. . Taking cognizance of their models, the model for this study was modified with respect to the objectives of the study and given as:

$\mathrm{Y}=\mathrm{f}(\mathrm{X})$

ECRTD-UK: https://www.eajournals.org/ 
Therefore, they functional relationships are expressed as follows:

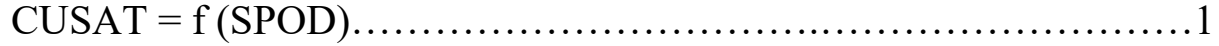

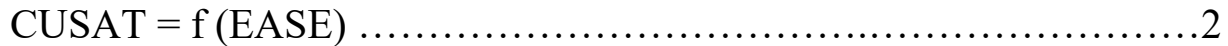

Hence, the model specification of the study will be:

CUSAT $_{i}=\beta_{0}+\beta_{1}$ SPOD $_{i}+\mu$--.--

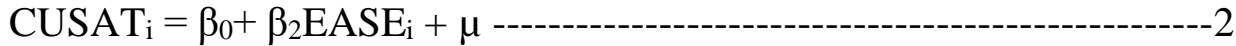

$\operatorname{CUSAT}_{i}=\beta_{0}+\beta_{1}$ SPOD $_{i}+\beta_{2}$ EASE $_{i}+\mu----5$

Where:

$\beta \mathrm{o}=$ base constant or the intercept

$\beta_{1}-\beta_{7}=$ beta regression coefficient for $\mathrm{x}$

\section{RESULT AND DISCUSSION}

\section{Descriptive Analysis}

A total number of 140 questionnaires were administered to respondents, which only 128 were returned. The remaining 12 questionnaires were either unreturned or wrongly filled that made them unusable. All the administered copies of questionnaire were considered valid for the analysis. Therefore, the analysis of the data was based on the copies which were correctly filled and returned through which the analyses of the study were presented.

Table 1 Distribution of Questionnaire

\begin{tabular}{|l|l|l|}
\hline & Frequency & Percentage (\%) \\
\hline Returned and duly completed & 128 & $91.6 \%$ \\
\hline Unreturned & 12 & $8.4 \%$ \\
\hline Total & 140 & $100 \%$ \\
\hline
\end{tabular}

Source: Field Survey, 2020

Socio-demographic Characteristics of Respondents

Analysis of Respondents by Socio-demographic Characteristics

Table 2 Percentage Distribution of Respondents by Socio-demographic Characteristics

\begin{tabular}{|l|l|l|}
\hline & Frequency & Percent $(\%)$ \\
\hline Age & & \\
\hline $18-25$ & 28 & 21.9 \\
\hline $26-35$ & 61 & 47.7 \\
\hline $36-59$ & 35 & 27.3 \\
\hline 60 and above & 4 & 3.1 \\
\hline Total & 128 & 100.0 \\
\hline Gender & & \\
\hline Male & 76 & 59.4 \\
\hline
\end{tabular}

ECRTD-UK: https://www.eajournals.org/

Journal level DOI: https://doi.org/10.37745/ejaafr.2013 
European Journal of Accounting, Auditing and Finance Research Vol.10, No. 2, pp.1-30, 2022

Print ISSN: 2053-4086(Print), Online ISSN: 2053-4094(Online)

\begin{tabular}{|l|l|l|}
\hline Female & 52 & 40.6 \\
\hline Total & 128 & 100.0 \\
\hline Marital Status & 46 & \\
\hline Single & 44 & 35.9 \\
\hline Married & 17 & 34.4 \\
\hline Separated & 21 & 13.3 \\
\hline Widow(er) & 128 & 16.4 \\
\hline Total & & 100.0 \\
\hline Years of Using Digital Service & 40 & \\
\hline $1-5$ years & 44 & 31.2 \\
\hline 6-10 years & 44 & 34.4 \\
\hline 11 years and above & 128 & 34.4 \\
\hline Total & & 100.0 \\
\hline Educational Level & 6 & \\
\hline Primary & 11 & 4.7 \\
\hline Secondary & 55 & 8.6 \\
\hline Tertiary School & 56 & 43.0 \\
\hline Others & 128 & 43.8 \\
\hline Total & & 100.0 \\
\hline Employment Class & 50 & \\
\hline Self Employed & 34 & 39.1 \\
\hline Civil Servant & 34 & 26.6 \\
\hline Student & 10 & 26.6 \\
\hline Retired & 128 & 7.8 \\
\hline Total & & 100.0 \\
\hline Digital Service often Use & 15 & \\
\hline POS & 25 & 11.7 \\
\hline M-Banking & 78.5 \\
\hline ATM & 5 & 3.9 \\
\hline Website & 5.9 \\
\hline Others & & 100.0 \\
\hline Total & & \\
\hline Source: & & \\
\hline
\end{tabular}

\section{Source: Field Survey, 2020}

ECRTD-UK: https://www.eajournals.org/

Journal level DOI: https://doi.org/10.37745/ejaafr.2013 


\section{Interpretation}

Table 2 above shows the percentage distribution of the respondents by socio-demographic characteristics. The table depicts that most of the respondents were between the age group of 2635 years with a percentage of $47.7 \%$ of the respondents. This means that most of the customers who use digital banking for different operation in the selected money banks were middle aged individuals. Hence, it can be concluded that middle aged respondents (26-35 years) were those who were well informed about digital banking as constituted in the questionnaire; thus, their opinion can be trusted. Table 4.2 shows that majority $(59.4 \%)$ of the respondents were male. Table 4.2 also shows the findings that majority of the respondents $(35.9 \%)$ were single. The table also indicates that most of the respondents have 6years and above years of using digital service.

Furthermore, Table 2 also shows that majority of the respondents had other forms of education (43.8\%). This means that their choice of using digital banking would be influenced by their level of education as depicted by the results of the study. In the same vein, it implies that educated and well informed respondents filled the questionnaire; thus, their opinion can be trusted. The table also shows the employment class of the respondents, of which majority of them $(30.1 \%)$ were selfemployed. The employment class of the respondents was showed in the table and it is seen that both civil servants and students has the highest percentage of the respondents (26.6\%), which shows that it information gotten will be rightly filled. Table 4.2 also shows that majority of the respondents use ATM followed by percentage of those who uses mobile banking (19.5\%).

Table 3 Measure of Digital Banking (Speed of Delivery)

\begin{tabular}{|l|l|l|l|l|l|l|}
\hline $\begin{array}{l}\text { Speed of } \\
\text { Delivery }\end{array}$ & Disagree & Undecided & Agree & $\begin{array}{l}\text { Strongly } \\
\text { Agree }\end{array}$ & Mean & Std. Dev. \\
\hline $\begin{array}{l}\text { I experience } \\
\text { few and } \\
\text { minimal } \\
\text { delays in e } \\
\text { banking } \\
\text { activities }\end{array}$ & $4(3.1 \%)$ & $28(21.9 \%)$ & $64(50.0 \%)$ & $32(25.0 \%)$ & 3.9688 & 0.77294 \\
\hline $\begin{array}{l}\text { Services } \\
\text { carried out on } \\
\text { digital } \\
\text { platform is } \\
\text { very prompt } \\
\text { and quick }\end{array}$ & $1(0.8 \%)$ & $24(18.8 \%)$ & $55(43.0 \%)$ & $48(37.5 \%)$ & 4.1719 & 0.75409 \\
\hline $\begin{array}{l}\text { I get detail of } \\
\text { my account } \\
\text { through } \\
\text { SMS/email on }\end{array}$ & $0(0.0 \%)$ & $18(14.1 \%)$ & $62(48.4 \%)$ & $48(37.5 \%)$ & 4.2344 & 0.68141 \\
\hline
\end{tabular}

ECRTD-UK: https://www.eajournals.org/

Journal level DOI: https://doi.org/10.37745/ejaafr.2013 


\begin{tabular}{|l|l|l|l|l|l|l|}
\hline $\begin{array}{l}\text { my GSM } \\
\text { phone }\end{array}$ & & & & & & \\
\hline $\begin{array}{l}\text { Using digital } \\
\text { banking } \\
\text { medium is } \\
\text { faster than } \\
\text { traditional } \\
\text { means of } \\
\text { banking }\end{array}$ & & $10(3.1 \%)$ & $80(62.5 \%)$ & $44(34.4 \%)$ & 4.3125 & 0.52870 \\
\hline $\begin{array}{l}\text { The speed of } \\
\text { transaction } \\
\text { using digital } \\
\text { banking can } \\
\text { be rate very } \\
\text { fast }\end{array}$ & $0(0.0 \%)$ & $10(7.8 \%)$ & $77(60.2 \%)$ & $41(32.0 \%)$ & 4.2422 & 0.58520 \\
\hline \begin{tabular}{l} 
Source \\
\hline
\end{tabular} & & & & & & \\
\hline
\end{tabular}

Source: Field Survey, 2020

\section{Interpretation}

The table above shows the responses of the respondents on the speed of digital banking with the use of speed of delivery.From Table 3, 3.1\% of the respondents disagreed that they experience few and minimal delays in E-banking activities; $21.9 \%$ neither agree nor disagree to the notion, 50\% agreed to this notion and $25 \%$ of the respondents strongly agreed. The mean responses of 3.96 showed that most of the respondents agreed that they experience few and minimal delays in Ebanking activities. The standard deviation of 0.77 further confirmed this result.

Minimal percentage of the respondents $(0.8 \%)$ disagreed that services carried out on digital platform is very prompt and quick, $18.8 \%$ of the respondents couldn't decide, $43.0 \%$ agreed to this notion, and $37.5 \%$ strongly agreed that services carried out on digital platform is very prompt and quick. The mean responses of 4.17 showed that most of the respondents agreed that the services carried out on digital platform are very prompt and quick. The standard deviation of 0.754 further buttressed this assertion. None of the respondents disagreed that they get detail of their account through SMS/email on their GSM phone, 14.1\% didn't decide on the notion, $48.4 \%$ agreed to this notion, and $37.5 \%$ strongly agreed that they get detail of their account through SMS/email on their GSM phone. The mean responses of 4.23 showed that most of the respondents agreed that they get detail of their account through SMS/email on their GSM phone. The standard deviation of 0.681 further buttressed this result.

Furthermore, Table 3 also shows that none of the respondents disagreed that using digital banking medium is faster than traditional means of banking, 3.1\% of the respondents were indecisive. Most

ECRTD-UK: https://www.eajournals.org/ 
of the respondents $(62.5 \%)$ agreed that using digital banking medium is faster than traditional means of banking and $34.4 \%$ strongly agreed to the view. The mean value of 4.312 suggests that most of the respondents agree that using digital banking medium is faster than traditional means of banking. The standard deviation value of 0.528 further confirms this claim.

Also from the table, none of the respondents disagreed that the speed of transaction using digital banking can be rate very fast; $7.8 \%$ neither agree nor disagree to the notion, $60.2 \%$ agreed to this notion and $32 \%$ of the respondents strongly agreed. The mean responses of 4.242 showed that most of the respondents agreed that the speed of transaction using digital banking can be rate very fast. The standard deviation of 0.585 further buttressed this assertion.

Table 4 Measure of Digital Banking (Ease of Use)

\begin{tabular}{|l|l|l|l|l|l|l|}
\hline Ease of Use & Disagree & Undecided & Agree & $\begin{array}{l}\text { Strongly } \\
\text { Agree }\end{array}$ & Mean & $\begin{array}{l}\text { Std. } \\
\text { Dev. }\end{array}$ \\
\hline $\begin{array}{l}\text { Electronic banking } \\
\text { can do everything } \\
\text { for me as easily } \\
\text { more than bank } \\
\text { employees do }\end{array}$ & $0(0.0 \%)$ & $23(18.0 \%)$ & $77(60.2 \%)$ & $28(21.9 \%)$ & 4.0391 & 0.63248 \\
\hline $\begin{array}{l}\text { Using electronic } \\
\text { banking avoid me } \\
\text { encountering } \\
\text { unpleasant } \\
\text { relationship with } \\
\text { bank employees }\end{array}$ & $0(0.0 \%)$ & $20(15.6 \%)$ & $67(52.3 \%)$ & $41(32.0 \%)$ & 4.1641 & 0.67319 \\
\hline $\begin{array}{l}\text { The website for } \\
\text { digital banking has } \\
\text { a lead and format } \\
\text { that makes it easy } \\
\text { to use }\end{array}$ & $0(0.0 \%)$ & $18(14.1 \%)$ & $69(53.9 \%)$ & $41(32.0 \%)$ & 4.1797 & 0.65729 \\
\hline $\begin{array}{l}\text { Products and } \\
\text { services associated } \\
\text { with my need are } \\
\text { easily seen in the } \\
\text { website and app }\end{array}$ & $1(0.8 \%)$ & $17(13.3 \%)$ & $61(47.7 \%)$ & $49(38.3 \%)$ & 4.2344 & 0,70414 \\
\hline
\end{tabular}

Source: Field Survey, 2020

\section{Interpretation}

The Table 4 above shows the measure of the respondents' response on the ease of use of digital banking.

ECRTD-UK: https://www.eajournals.org/

Journal level DOI: https://doi.org/10.37745/ejaafr.2013 
From the table 4, none of the respondents disagreed that electronic banking can do everything for them as easily more than bank employees do; $18.0 \%$ neither agree nor disagree to the notion, $60.2 \%$ agreed to this notion and $21.9 \%$ of the respondents strongly agreed. The mean responses of 4.039 showed that most of the respondents agreed that electronic banking can do everything for them as easily more than bank employees do. The standard deviation of 0.632 further buttressed this assertion.

None of the respondents disagreed that using electronic banking helped them to avoid encountering unpleasant relationship with bank employees, $15.6 \%$ were undecided, $52.3 \%$ agreed to this notion, and $32 \%$ strongly agreed that using electronic banking helped them to avoid encountering unpleasant relationship with bank employees. The mean responses of 4.164 showed that most of the respondents agreed that using electronic banking helped them to avoid encountering unpleasant relationship with bank employees. The standard deviation of 0.673 further buttressed this assertion. None of the respondents disagreed that the website for digital banking has a lead and format that makes it easy to use, $14.1 \%$ were undecided, $53.9 \%$ agreed to this notion, and $32.0 \%$ strongly agreed that the website for digital banking has a lead and format that makes it easy to use. The mean responses of 4.17 showed that most of the respondents agreed that the website for digital banking has a lead and format that makes it easy to use. The standard deviation of 0.657 further buttressed this assertion.

Furthermore, Table 4 also shows $0.8 \%$ of the respondents disagreed that, $13.3 \%$ of the respondents were indecisive. Most of the respondents consisting of $47.7 \%$ of the respondents agreed that products and services associated with their need are easily seen in the website and app and $38.4 \%$ strongly agreed to the view. The mean value of 4.23 suggests that products and services associated with their need are easily seen in the website and app. The standard deviation value of 0.704 further confirms this claim.

Test of Hypothesis One ( $\left.\mathrm{H}_{01}\right)$

Research Objective One: Determine the effect of speed of delivery on customers' satisfaction of money deposit banks in Lagos State, Nigeria.

Research Question One: What is the effect of speed of delivery of on customers' satisfaction of deposit money banks in Lagos State, Nigeria?

Research Hypothesis One $\left(\mathrm{H}_{01}\right)$ : Speed of delivery has no significant effect on customers' satisfaction of deposit money banks in Lagos State, Nigeria.

ECRTD-UK: https://www.eajournals.org/

Journal level DOI: https://doi.org/10.37745/ejaafr.2013 
Table 5 Regression Estimate

\begin{tabular}{|l|l|l|l|l|}
\hline \multirow{2}{*}{ Variable } & \multicolumn{4}{|c|}{ Model 1 } \\
\cline { 2 - 5 } & Coefficient & Std Error & t-Stat. & Prob. \\
\hline C & 2.652 & 0.328 & 8.085 & $0.000^{*}$ \\
\hline SPOD & 0.408 & 0.078 & 5.250 & $0.000^{*}$ \\
\hline R $^{2}$ & 0.179 & & \\
\hline Adjusted R & & & \\
\hline S.E of Reg & 0.173 & & \\
\hline F-Statistic & 0.46864 & & \\
\hline Prob.(F-Stat) & 27.559 & & \\
\hline Obs & $0.000^{*}$ & & \\
\hline
\end{tabular}

Dependent Variable: Customers' Satisfaction

*significance at $5 \%$

Source: Researcher's Study, 2020

Model 1

CUSAT $_{i}=\alpha_{1}+\beta_{1}$ SPOD $_{i}+\mu_{1}$

$\operatorname{CUSAT}_{i}=2.652+0.408$ SPOD $_{i}$

\section{Interpretation}

Hypothesis one of this study is aimed to examine if speed of delivery has no significant effect on customer satisfaction of deposit money banks in Nigeria. In fulfillment of the objective one, research question one and hypothesis one of this study, speed of delivery was used as independent variable while customer satisfaction was used as dependent variable. Observable in the result presented above, the independent variables employed were examined and decisions were made using the p-values of the results. Considering the signs and magnitude of the estimated parameters, the values of the coefficient of speed of delivery was positive. A unit change in speed of delivery will increase the customer satisfaction by 0.408 . The value of the constant implies that if the independent variable employed does not exist, customer satisfaction will maintain a positive value of 2.652 .

The co-efficient of determination $\left(\mathrm{R}^{2}\right)$ is 0.179 . This means that about $18 \%$ variation in customers satisfaction is explained by accessibility while the remaining $82 \%$ will be accounted for by other factors not included in the model. The adjusted $\mathrm{R}^{2}$ value of $17 \%$ for $\mathrm{R}^{2}$ reassured the ability of the independent variables to collectively explain any variation in the dependent variable up to these numbers of percentage even if the observations and variables are infinitely enlarged. The adjusted $\mathrm{R}^{2}$ value of $17.3 \%$ for $\mathrm{R}^{2}$ reassured the ability of the independent variable to collectively explain any variation in the dependent variable up to these numbers of percentage even if the observations and variables are infinitely enlarged. The adjusted $R^{2}$ value of $17.3 \%$ for speed of delivery reassured the ability of the independent variable to explain any variation in the dependent variable up to the numbers of percentage even if the observations and variable are infinitely enlarged. The explanatory power of the regression model with an adjusted $\mathrm{R}^{2}$ of 0.173 is not impressive. This

ECRTD-UK: https://www.eajournals.org/

Journal level DOI: https://doi.org/10.37745/ejaafr.2013 
implies that there is good fit of the model, showing that there is a strong positive relationship between the regressors (independent variables) and the regressed (dependent variable).

The t-statistics reflects the significance of the variable in the model. From the above presented result, speed of delivery has significant effect on the customers' satisfaction at 5\% level of significance. The F-statistics measures the overall performance of the model employed in the study. The F-statistics value for this study is 27.559. The significance of this variable is ascertained using the p-values. From the results above, the p-value for speed of delivery is less than 0.05. Considering this, this study shows that speed of delivery have significant effect on customers' satisfaction.

At a level of significance 0.05 , the F-Statistics is 27.559 , while the p-value of the F-Statistics is 0.000 which is less than 0.05 adopted, The study therefore rejected the null hypothesis which means that speed of delivery significantly affect customers' satisfaction of the selected banks in this study.

\section{Test of Hypothesis Two (Ho2)}

Research Objective Two: assess the effect of ease of use on customers' satisfaction of money deposit banks in Lagos State, Nigeria.

Research Question Two: What is the effect ease of use on customers' satisfaction in deposit money bank in Lagos State, Nigeria?

Research Hypothesis Two $\left(\mathrm{H}_{02}\right)$ : Ease of use has no significantly effect on customers' satisfaction of customers in deposit money banks in Lagos state Nigeria.

Table 6 Regression Estimate

\begin{tabular}{|l|l|l|l|l|}
\hline \multirow{2}{*}{ Variable } & \multicolumn{3}{|l|}{ Model 2 } & \multicolumn{2}{|l|}{} \\
\cline { 2 - 5 } & Coefficient & Std Error & t-Stat. & Prob. \\
\hline C & 2.052 & 0.286 & 7.175 & $0.000^{*}$ \\
\hline EASE & 0.556 & 0.068 & 8.143 & $0.000^{*}$ \\
\hline $\mathbf{R}^{2}$ & 0.345 & & & \\
\hline Adjusted R & $\mathbf{2}$ & & \\
\hline S.E of Reg & 0.340 & & \\
\hline F-Statistic & 0.41877 & & \\
\hline Prob.(F-Stat) & 66.312 & & \\
\hline Obs & $0.000^{*}$ & & & \\
\hline
\end{tabular}

Dependent Variable: Customers' Satisfaction

*significance at 5\%

Source: Researcher's Study, 2020

Model 2

$\operatorname{CUSAT}_{\mathrm{i}}=\alpha_{1}+\beta_{1} \mathrm{EASE}_{\mathrm{i}}+\mu_{1}$

CUSAT $_{i}=2.052+0.556 \mathrm{EASE}_{\mathrm{i}}$

ECRTD-UK: https://www.eajournals.org/

Journal level DOI: https://doi.org/10.37745/ejaafr.2013 


\section{Interpretation}

Hypothesis two of this study is aimed to examine if ease of use has no significant effect on customers' satisfaction of deposit money banks in Lagos State, Nigeria. In fulfillment of the objective one, research question one and hypothesis one of this study, ease of use was used as independent variable while customers' satisfaction was used as dependent variable. Observable in the result presented above, the independent variables employed were examined and decisions were made using the $\mathrm{p}$-values of the results. Considering the signs and magnitude of the estimated parameters, the values of the coefficient of ease of use was positive. A unit change in ease of use will increase the customers' satisfaction by 0.556 . The value of the constant implies that if the independent variable employed does not exist, customers' satisfaction will maintain a positive value of 2.052 .

The co-efficient of determination $\left(\mathrm{R}^{2}\right)$ is 0.345 . This means that about $34 \%$ variation in customers satisfaction is explained by the control variables (education, age and attitude of customers) while the remaining $71 \%$ will be accounted for by other factors not included in the model. The adjusted $\mathrm{R}^{2}$ value of $34 \%$ for $\mathrm{R}^{2}$ reassured the ability of the independent variables to collectively explain any variation in the dependent variable up to these numbers of percentage even if the observations and variables are infinitely enlarged. The adjusted $\mathrm{R}^{2}$ value of $34 \%$ for $\mathrm{R}^{2}$ reassured the ability of the independent variables to collectively explain any variation in the dependent variable up to these numbers of percentage even if the observations and variables are infinitely enlarged. The adjusted $\mathrm{R}^{2}$ value of $34 \%$ for ease of use reassured the ability of the independent variable to explain any variation in the dependent variable up to the numbers of percentage even if the observations and variable are infinitely enlarged. The explanatory power of the regression model with an adjusted $\mathrm{R}^{2}$ of 0.340 is impressive. This implies that there is good fit of the model, showing that there is a strong positive relationship between the regressors (independent variables) and the regressed (dependent variable).

The t-statistics reflects the significance of the variable in the model. From the above presented result, ease of use have significant effect on the customers' satisfaction at 5\% level of significance. The F-statistics measures the overall performance of the model employed in the study. The Fstatistics value for this study is 66.312. The significance of this variable is ascertained using the pvalues. From the results above, the p-value for ease of use is less than 0.05 . Considering this, this study shows that ease of use have significant effect on customers' satisfaction.

At a level of significance 0.05 , the F-Statistics is 66.312, while the p-value of the F-Statistics is 0.000 which is less than 0.05 adopted, The study therefore rejected the null hypothesis which means that ease of use significantly affect customers' satisfaction of the selected banks in this study.

ECRTD-UK: https://www.eajournals.org/

Journal level DOI: https://doi.org/10.37745/ejaafr.2013 


\section{DISCUSSION OF FINDINGS}

The first part dealt with demographic characteristics of the respondents. The summary of the responses obtained from the returned copies of the questionnaire showing that majority of the respondents are male i.e. 59.4\% of the entire population of the respondents are male. It also shows that majority of the respondents are between the age bracket of 26-35 years, consisting $47.7 \%$ of the total respondents. This implies that the designated respondent fell among the average age bracket of the four age groupings in our questionnaire. Hence, it can be said that well informed respondents filled the questionnaire; thus, their opinion can be trusted. The study also showed the marital status of the respondents, majority of the respondents were single consisting $35.9 \%$ of the total respondents. Furthermore, the table shows the most of the respondents of this study has spent 6-11 years and above using digital services. They account for about $68.8 \%$ of the total respondents. Also, the educational level of the respondent's shows that majority of the respondent has other forms of education consisting of about $43.8 \%$.

The table also shows that majority of the respondents are self-employed, consisting of $39.1 \%$ or the total respondents. Hence, it can be said that working class people filled the questionnaire; thus, their opinion can be trusted. Finally, the table reveals that majority of the respondents use the ATM often, which is a total of $60.9 \%$ of the total respondents.

The regression estimates of model 1 shows speed of delivery have no significant effect on customer satisfaction of the selected Banks in this study. This result is inconsistence with the a priori expectation that there is no significant impact of speed of delivery on the customer satisfaction of Nigeria deposit money banks. The result was corroborated by the probability value of the $F$ statistics of 0.000 which shows that the regression result is statistically significant because this is greater than 5\%, the level of significant adopted for this study. This implies that speed of delivery thus has no impact on customer satisfaction of the selected Nigerian money banks. The findings of this study is consistent with that of Babatunde and Salawudeen (2017) where they listed some banking services that have been revolutionized through the use of ICT as including account opening, customer account mandate, and transaction processing an recording. According to Dixit and Datta (2018) in their research, who studied the impact of computer automation on the banking services in Lagos and discovered that E-Banking has tremendously improved the services of some banks to their customers in Lagos. The study was however restricted to the commercial nerve center of Nigeria and concentrated on only six banks. He made a comparative analysis between the old and new generation banks and discovered variation in the rate of adoption of the automated devices.

The regression estimates of model 2 shows that ease of use significantly affect customers' satisfaction of the selected Banks in this study. This result is inconsistence with the a priori expectation that there is no significant effect of ease of use on the relevance of customers'

ECRTD-UK: https://www.eajournals.org/

Journal level DOI: https://doi.org/10.37745/ejaafr.2013 
satisfaction of Nigeria deposit money banks. The result was also corroborated by the probability of the $F$ statistics 0.000 which shows that the regression result is statistically significant because this is less than 5\%, the level of significant adopted for this study. This implies that ease of use thus impact on relevance of the customers' satisfaction of the selected Nigeria money banks. The findings of this study is consistent with the study of Geeta \& Surendra (2014), who in his study affirms that when a firm gains permission to operate from the society, it is ultimately accountable to the society for how it operates and what it does because the society provides corporations authority to own and use natural resources and to hire employees.

\section{CONCLUSION}

The research concluded that digital banking convenience which is determined by speed of delivery, ease of use, privacy and security and accessibility has a significant effect on customers' satisfaction of the selected deposit money banks (DBMs) in Nigeria.

\section{Recommendations}

i. The gains of this innovation be consolidated through provision of more service points and user-friendly customer-oriented financial products.

ii. Digital Banking service providers should also continuously upgrade their facilities to meet the changing demands of the customer.

\section{REFERENCES}

Adeyemi, O. A., Ola, O. S. \& Oyewole, F. A. (2014). Internet banking functionality in Nigeria and outcomes of customer satisfaction: An empirical investigation. International Journal of Academic Research in Business and Social Sciences, 4(8), 2222-6990

Ahmad, A. E. M. K., \& Al-Zu'bi, H. A. (2011). E-banking functionality and outcomes of customer satisfaction: an empirical investigati17.) on. International journal of marketing studies, 3(1), 50-65.

Aldawani, A. M., \& Palvia, P. C. (2002). Developing and validating an instrument for measuring user-perceived web quality. In Information \& Management [interaktyvus]. 39(6), P. 467476.

Alice, M. M., Elizabeth, N. M. \& Gregory, S. N. (2016). Effect of mobile banking on customer satisfaction in selected banks in Trans-Nzoia County. International Journal of Recent Research in Commerce Economics and Management, 3(4), 12-22.

Amoah-Mensah, A. (2010). Customer satisfaction in the banking industry: a comparative study of Ghana and spain (Doctoral dissertation). Retrieved from ProQuest Dissertation and Theses database.

Anderson, J. R. (2014). Rules of the mind. Psychology Press.

Anyim, F. C., Ikemefuna, C. O., \& Mbah, S. E. (2011) 'Human resource management challenges in Nigeria under a globalized economy', International Journal of Economics \&

ECRTD-UK: https://www.eajournals.org/

Journal level DOI: https://doi.org/10.37745/ejaafr.2013 
European Journal of Accounting, Auditing and Finance Research

Vol.10, No. 2, pp.1-30, 2022

Print ISSN: 2053-4086(Print),

Online ISSN: 2053-4094(Online)

Management Sciences, 1(4), pp. 01-11. Available at: http://www.managementjournals.org (Accessed: 4 May, 2017).

Ariff, M. S. M., Yun, L. O., Zakuan, N., \& Ismail, K. (2013). The impacts of service quality and customer satisfaction on customer loyalty in internet banking. Procedia-Social and Behavioral Sciences, 81, 469-473.

Asadollah, K., Hossein, A. M. \& Abbas I. (2014). The impact of e-baking service quality dimensions on customers' satisfaction and brand equity (Case Study: Refah Bank, Tehran). Business and Management Research, 2(4), 25-37.

Babatunde, M. O. \& Salawudeen, M. O. (2017). Impact of electronic banking on customers' satisfaction in Nigeria. Greener Journal of Business and Management Studies, 7(3), 30-42.

Bareerah, K., \& Muhammad, R. (2014). Factors contributing to customer loyalty in commercial banking. Journal of market research. ISSN 2016-3082. 4(2), 413-431.

Black, E. D. (2001). An introduction to Pound-Drever-Hall laser frequency stabilization. American journal of physics, 69(1), 79-87.

Dixit, N. \& Datta. S. K. (2018). Acceptance of E-banking Among Customers: An Empirical Investigation in India. Journal of Management and Science, 15(2), 1-17.

Gakure, R. \& Ngumi, A. (2013). Bank innovation and profitability of commercial banks in Kenya. Prime Journal of Social Sciences, 5(3), 88-96.

Gallino, S., \& Moreno, A. (2014). Integration of online and offline channels in retail: The impact of sharing reliable inventory availability information. Management Science, 60(6), 14341451.

Geeta, S. \& Surendra, M. (2014). Internet banking service quality and its impact on customer satisfaction in Indore district of Madhya Pradesh. International Journal of Business and Management Invention, 3(3), 1-6.

Gupta, K. K., \& Bansal, I. (2012). Development of an instrument to measure internet banking service quality in India. Researchers World, 3(2 Part 2), 11.

Husein, S. (2013). Online corporate social responsibility disclosure in the Gulf cooperation countries. Review of Accounting and Finance, 1(2), 90-103.

Hunt, J. (2011). Which immigrants are most innovative and entrepreneurial? Distinctions by entry visa. Journal of Labor Economics, 29(3), 417-457.

Jamal, M., \& Naser, J. (2002). Customer satisfaction and retail banking: An assessment of some of the key antecedents of customer satisfaction in retail banking, International Journal of Bank Marketing, 20(4), 146-160.

Johnson, M. D., \& Fornell, C. (1991). A framework for comparing customer satisfaction across individuals and product categories. Journal of Economic Psychology, 12(2), 267-86.

Karim, R., \& Chowdhury, T. (2014). Customer satisfaction on service quality in private commercial banking sector in Bangladesh. British Journal of Marketing Studies, 2(2), 111.

Kevin, O. M. \& Harriet, K. (2015). Accessibility of digital banking on customer satisfaction: National bank of Kenya. Journal of Business and Management, 17(11), 48-54.

ECRTD-UK: https://www.eajournals.org/

Journal level DOI: https://doi.org/10.37745/ejaafr.2013 
European Journal of Accounting, Auditing and Finance Research

Vol.10, No. 2, pp.1-30, 2022

Print ISSN: 2053-4086(Print),

Online ISSN: 2053-4094(Online)

Khorasani-Zavareha, D., Bigdelic, M., Eslamlou, H. F., Abdoosd, H., \& Mohammadib, R. (2012). Journal of Clinical Research \& Governance. J Clin Res Gov, 1, 25.

Kumar, V. M. (2014). Retail banking: Delivering a meaningful digital customer experience. Retrieved from www.cognizant.com/InsightsWhitepapers/Retail-Banking-Delivering-aMeaningful-Digital-Customer-Experience-codex1036.

Marcel, T. N. \& Prisca, S. N. (2015). Customer relationship management and firms performance: Revisiting the case of the CAMCCUL microfinance institutions. International Journal of Information Technology and Business Management, 38(1), 12-21.

Maxham, J. (2014). The Art of Troubleshooting. Jason Maxham.

McMullen, J. S., \& Bergman Jr, B. J. (2017). Social entrepreneurship and the development paradox of prosocial motivation: A cautionary tale. Strategic Entrepreneurship Journal, 11(3), 243270.

Mohsin, Z., Arshad, Z., Saleem, U. \& Kashif R. (2011). Impact of online service quality on customer satisfaction in banking sector of Pakistan. African Journal of Business Management, 5(30), 11786-11793.

Mammasse, N., \& Schlich, P. (2014). Adequate number of consumers in a liking test. Insights from resampling in seven studies. Food quality and preference, 31, 124-128.

Monireh, R., Asadollah, K. \& Reza, K. (2014). The effects of employees' customer orientation, customer satisfaction and commitment on customers' sustainability. Arabian Journal of Business and Management Review, 4(1), 109-121.

Muhsina J. \& Imran A. (2015). Factors influencing customer satisfaction of mobile banking Services: A Study on Second - Generation Banks. European Journal of Business and Management, 7(26), 2222-2839.

Naeem, A., Muniba, L., Qurat-Ul-Ain, A. \& Amna, A. (2016). The impact of service quality, customer satisfaction and loyalty programs on customer loyalty. International Review of Management and Business Research, 5(3), 817-826.

Ondiege, P. (2010). Mobile banking in Africa: taking the bank to the people. Africa Economic Brief, 1(8), 1-16.

Oliver, P. (2010). The student's guide to research ethics. McGraw-Hill Education (UK).

Saha, P., \& Zhao, Y. (2005). Relationship between online service quality and customer satisfaction: a study in internet banking.

Santhiyavalli, G. (2011) “Customer's Perception of Service Quality of State Bank of India- A factor analysis. International Journal of Management and Business Studies. 1(3).

Sarokolaei, M. A., Rahimipoor, A., Nadimi, S., \& Taheri, M. (2012). The investigating of barriers of development of e-banking in Iran. Procedia-Social and Behavioral Sciences, 62, 11001106.

Scholten, B. \& Wensveen, D. (2003). A critique on the theory of financial intermediation. Journal of Monetary Economics, 17(2), 271-291.

Seyed, F. A., Razieh, K. \& Ali, A. (2015). The evaluation of the effect of electronic banking in customer satisfaction and loyalty. International Journal of Marketing Studies, 7(2), 19182203.

ECRTD-UK: https://www.eajournals.org/

Journal level DOI: https://doi.org/10.37745/ejaafr.2013 
European Journal of Accounting, Auditing and Finance Research

Vol.10, No. 2, pp.1-30, 2022

Print ISSN: 2053-4086(Print),

Online ISSN: 2053-4094(Online)

Shittu, I. (2012). Financial intermediation and economic growth in Nigeria. British Journal of Arts and Social Sciences, 4(2), 164-179.

Sinisalo, J. \& Salo, H. (2007). Mobile customer relationship management: Underlying issues and challenges. Journal of Business Management Research, 6(2), 102-107

Sreejesh, S., \& Mohapatra, S. (2013). Mixed method research design: an application in consumerbrand relationships (CBR). Springer Science \& Business Media.Swaid,,S. I., Wigand, R.T. (2007). Key dimensions of e-commerce service quality and its relationships to satisfaction and loyalty. Journal of Technological Innovations in Banking, 3(2), 76-89.

Tasmin, R., Abubakar, A., Norazlin, H. \& Josu, T. (2013). Impact of online banking on customer service delivery in Malaysian banking industry. Technological innovation and Industrial management, 29(31), 54-175.

Truch, E. (2006). Lean consumption and its influence on brand. Journal of Consumer Behaviour: An International Research Review, 5(2), 157-165.

Vasya, K. \& Patrik J. (2006). Quality Online Banking Services. Bachelors, Thesis, Jönköping University.

Wang, Y. \& Lin, M. (2011). Determinants of user acceptance of internet banking. International Journal of Service Industry Management, 14(5), 501-519.

Worku, G. Tilahun, A. \& Tafa, M. A.(2016).The impact of electronic banking on customers ' satisfaction in Ethiopian banking industry (The Case of Customers of Dashen and Wogagen Banks in Gondar City). Journal of Business Finance, 5(2), 2167-2234.

Wu, J. H. \& Wang, S. C. (2005). What drives mobile commerce? An empirical evaluation of the revised technology acceptance model. Journal of Information \& Management, 42(5), 719729.

Yan, Y. \& Fengjie, J. (2009). The empirical study on the factors influencing customer's e-loyalty. International Business Research, 7(10), $169-186$

Yoon, C. (2010). Antecedents of customer satisfaction with online banking in China: The Effects of experience. Journal of Computers in Human Behavior, 26(4), 1296-1304.

Zeithaml, V. A., Parasuraman, A. \& Malhotra, A. (2002). Service quality delivery through Website. Journal of Academy of Marketing Science, 52(4), 2-22.

Zhengwei, M. \& Zhao, J. (2012). Evidence on e-banking customer satisfaction in the China commercial bank sector. Journal of Software Banking, 7(4), 927-933.

ECRTD-UK: https://www.eajournals.org/

Journal level DOI: https://doi.org/10.37745/ejaafr.2013 